\title{
Prevalence of medulloblastoma in basal cell nevus syndrome patients with a PTCH1 mutation
}

Citation for published version (APA):

Verkouteren, B. J. A., Cosgun, B., Vermeulen, R. J., Reinders, M. G. H. C., van Geel, M., Gille, J. J. P., \& Mosterd, K. (2021). Prevalence of medulloblastoma in basal cell nevus syndrome patients with a PTCH1 mutation. Neuro-oncology, 23(6), 1035-1036. https://doi.org/10.1093/neuonc/noab048

Document status and date:

Published: 01/06/2021

DOI:

10.1093/neuonc/noab048

Document Version:

Publisher's PDF, also known as Version of record

Document license:

Taverne

Please check the document version of this publication:

- A submitted manuscript is the version of the article upon submission and before peer-review. There can be important differences between the submitted version and the official published version of record.

People interested in the research are advised to contact the author for the final version of the publication, or visit the DOI to the publisher's website.

- The final author version and the galley proof are versions of the publication after peer review.

- The final published version features the final layout of the paper including the volume, issue and page numbers.

Link to publication

\footnotetext{
General rights rights.

- You may freely distribute the URL identifying the publication in the public portal. please follow below link for the End User Agreement:

www.umlib.nl/taverne-license

Take down policy

If you believe that this document breaches copyright please contact us at:

repository@maastrichtuniversity.nl

providing details and we will investigate your claim.
}

Copyright and moral rights for the publications made accessible in the public portal are retained by the authors and/or other copyright owners and it is a condition of accessing publications that users recognise and abide by the legal requirements associated with these

- Users may download and print one copy of any publication from the public portal for the purpose of private study or research.

- You may not further distribute the material or use it for any profit-making activity or commercial gain

If the publication is distributed under the terms of Article $25 \mathrm{fa}$ of the Dutch Copyright Act, indicated by the "Taverne" license above, 


\section{Prevalence of \\ medulloblastoma in basal cell nevus syndrome patients with a PTCH1 mutation}

Patients with basal cell nevus syndrome (BCNS) are at risk of developing a medulloblastoma (MB) in childhood, which usually develops before the age of $3 .^{1,2}$ The incidence of $\mathrm{MB}$ seems to differ between PTCH1 and SUFU heterozygotes. Knowledge of the prevalence of $\mathrm{MB}$ is important to guide screening, which is performed by MRI. In the consensus statement of the international colloquium on BCNS published in 2011, yearly MRI screening is advised in all BCNS children. ${ }^{1}$ However, more recently, a British cohort showed a MB prevalence of $33.3 \%$ in 9 SUFU heterozygotes and $2.4 \%$ in 126 PTCH1 heterozygotes. ${ }^{3}$ Based on this study, a recent guideline on cancer surveillance in patients with BCNS advised not to screen in $\mathrm{PTCH} 1$ heterozygotes and screen SUFU heterozygotes more frequently (ie, every 4 months during the first 3 years and half-yearly till the age of 5$).{ }^{4}$ For more robust evidence on the low incidence of MB among PTCH1 heterozygotes, we determined the prevalence of $\mathrm{MB}$ in a Dutch cohort.

A retrospective cohort study was conducted at the VU University Medical Center (VUMC) and the Maastricht University Medical Center+ (MUMC+) in the Netherlands. ${ }^{5}$ Between April 1999 and December 2015, the laboratories of those two hospitals processed all clinical requests for PTCH1 mutation analysis in the Netherlands and various foreign hospitals. Analysis was done by standard PTCH1 mutation analysis (Sanger sequencing) and multiplex ligation-dependent probe amplification (MLPA). After a search for PTCH1 analysis requests in the electronic genetic medical record system of the VUMC and MUMC+, patients with a pathogenic PTCH1 mutation were selected. Foreign patients were excluded due to practical difficulties. Information about MB presence was retrieved from the medical records from October 2015 until December $2016 .{ }^{5}$ The medical records of all patients aged $<8$ years at initial data assessment were reassessed between May 2020 and August 2020 to exclude MB development. Clinical data were available for 83 patients (from 77 families) with a pathogenic PTCH1 mutation. Two further cases were excluded because of intrauterine fetal death. One patient was 4 years old at the time of data collection, all other patients were $\geq 8$ years.

Of the 81 found mutations, 27 (33.3\%) were nonsense, 25 $(30.9 \%)$ frameshift, 11 (13.6\%) splicing, 10 (12.3\%) missense, 5 $(6.2 \%)$ in-frame duplications and deletions, and $3(3.7 \%)$ whole PTCH1 gene deletions.

Only 1 of the $81(1.2 \%)$ PTCH1 patients was diagnosed with a $\mathrm{MB}$ at the age of 11 months. The patient had a germline $\mathrm{PTCH} 1$ nonsense mutation in exon 12, c.1691T>G, which results in a stop at position 564 (p.Leu564*). He suffered from many other congenital anomalies, not all typical for BCNS.

Guidelines for patients with BCNS advise screening for MB with MRI. ${ }^{1,4}$ However, screening with MRI often requires general anesthesia in young children which can be stressful for parents and children. Moreover, the developmental risk of general anesthesia at young age is still under debate and high-frequency general anesthesia should therefore be performed only with caution. ${ }^{6}$ In this nationwide retrospective cohort study, we found a MB prevalence of $1.2 \%$ in $\mathrm{PTCH} 1$ heterozygotes. Taking into account the disadvantages of MRI and the low MB prevalence in two PTCH1 cohorts, high-frequency routine neuroimaging for $\mathrm{MB}$ in children with BCNS with an underlying $\mathrm{PTCH} 1$ mutation is debatable. We advocate to perform MRI in PTCH1 heterozygotes only when clinical symptoms are present. With this strategy, it is essential to monitor the development and skull growth of children twice per year during the first years of life.

\section{Funding}

None declared.

Conflict of interest statement. The authors have no conflict of interest to declare.

Authorship statement. All authors have seen and approved the manuscript.

Babette J. A. Verkouteren ${ }^{\oplus}$, Betül Cosgun, R. Jeroen Vermeulen, Marie G. H. C. Reinders, Michel van Geel, Johan J. P. Gille, and Klara Mosterd

Department of Dermatology, Maastricht University Medical Center, Maastricht, the Netherlands (B.J.A.V., B.C., M.G.H.C.R., M.V.G., K.M.); GROW School for Oncology and Developmental Biology, Maastricht University, Maastricht, the Netherlands (B.J.A.V., B.C., M.G.H.C.R., M.V.G., K.M.); Department of Neurology, Maastricht University Medical Center, Maastricht, the Netherlands (R.J.V.); Department of Clinical Genetics, Maastricht University Medical Center, Maastricht, the Netherlands (M.V.G.); Department of Clinical Genetics, VU University Medical Center, Amsterdam, the Netherlands (J.J.P.G.) 
Corresponding Author: Babette J. A. Verkouteren, MD, Department of Dermatology, Maastricht University Medical Center, P. Debyelaan 25, 6229 HX Maastricht, the Netherlands (babette.verkouteren@mumc.nl).

\section{References}

1. Bree AF, Shah MR; BCNS Colloquium Group. Consensus statement from the first international colloquium on basal cell nevus syndrome (BCNS). Am J Med Genet A. 2011;155A(9):2091-2097.
2. Waszak SM, Robinson GW, Gudenas BL, et al. Germline elongator mutations in sonic hedgehog medulloblastoma. Nature. 2020;580(7803):396-401.

3. Evans DG, Oudit D, Smith MJ, et al. First evidence of genotypephenotype correlations in Gorlin syndrome. J Med Genet. 2017:54(8):530-536.

4. Foulkes WD, Kamihara J, Evans DGR, et al. Cancer surveillance in Gorlin syndrome and rhabdoid tumor predisposition syndrome. Clin Cancer Res. 2017;23(12):e62-e67.

5. Cosgun B, Reinders MGHC, van Geel M, et al. Lack of genotype-phenotype correlation in basal cell nevus syndrome: a Dutch multicenter retrospective cohort study. J Am Acad Dermatol. 2020;83(2):604-607.

6. Vutskits L, Davidson A. Update on developmental anesthesia neurotoxicity. Curr Opin Anaesthesiol. 2017;30(3):337-342. 